\section{Ксенія СМИРНОВА}

\section{Еволюція джерел права Свропейського Союзу ${ }^{1}$}

\begin{abstract}
Форми фіксації норм права Євросоюзу виступають визначальним чинником розвитку європейського інтеграційного об'єднання та мають характерні особливості, акумулюючи в собі елементи джерел міжнародного та внутрішнього права. Лісабонський договір в цілому на змінює загальної будови системи джерел права Євросоюзу, систематизував нормативно-правові акти, поділяючи їх на категорії законодавчих та незаконодавчих. Проаналізовано тенденції систематизації нормативно-правових актів СС, а також роль джерел права ЄС у зовнішній політиці ЄС.

Ключові слова: Європейський Союз, джерела права, Лісабонський договір, acquis, sui generis, регламент, директива, рішення, рекомендація, висновок, законодавчі акти, незаконодавчі акти.
\end{abstract}

Fixing forms of the EU norms are formulated as the determinating factor of the European integration development that have own features accumulating elements of the international and national law sources. Lisbon Treaty doesn't change the whole system of the sources, otherwise following the practice, the Reform Treaty classifies legal acts into category of legislative and nonlegislative. The tendency of systematization of acts was described as well as their role in the EU external relations.

Keywords: European Union, sources of law, Lisbon Treaty, acquis, sui generis, regulation, directive, decision, recommendation, opinion, legislative acts, nonlegislative acts.

Право Європейського Союзу, що формувалося більше ніж півстоліття, представляє собою громіздку систему правових інструментів, які регулюють процеси інтеграції в європейському просторі. Правопорядок Європейського Союзу (Свросоюзу, ЄС) становить якісно нову форму інтеграції держав, за рівнем якої вона не має аналогів у світі. Новий правовий порядок Свросоюзу відрізняється як від міжнародного, так і від внутрішнього правопорядку держав. Особливий «автономний» правопорядок Євросоюзу має власну систему правових актів для регулювання суспільних відносин на виконання цілей та завдань установчих договорів європейських інтеграційних організацій.

Реформування Свропейського Союзу у зв'язку з набуттям чинності 31 грудня 2009 року Лісабонським договором необхідне було для подальшого міцного функціонування Євросоюзу, посилення ефективності та його демократизації, позначилося на зміні організації наддержавного комплексу правових інструментів.

Сучасні процеси інтеграції свідчать, що 10-річний період ознаменувався сталістю, й ЄС потребує подальшого модернізації своєї правової системи у випадку завершення процедури виходу Великої Британії з ЕС.

Лісабонський договір (Договір про Євросоюз (ДСС) та Договір про функціонування Євросоюзу (ДФСС)) - це новий основний договір Європейського союзу. Він вступив в силу з 1 грудня 2009 року. Й саме дана стаття присвячена 10-річчю святкування вступу в силу «реформованого» Свропейського Союзу із здобутою de jure міжнародною правосуб'єктністю. Мета нового договору було спростити і внести ясність у процес прийняття рішень Союзом. За допомогою договору були змінені ролі, завдання та склад інститутів та органів Євросоюзу, щоб вони відповідали потребам розширеного союзу. Таким чином, договір дає відповідь на питання: «Хто і що робить в СС і коли?»

1 Дана стаття базується на матеріалах раніше виданої статті: Смирнова К.В. Джерела права Свропейського Союзу: новітні тенденції розвитку // Право України. 2017. №6. С. 90-97.

УДК 341.1

https://doi.org/10.36952/ujil.2019.4.106

() К. Смирнова, 2019
СМИРНОВА Ксенія Володимирівна доктор юридичних наук, професор, професор кафедри порівняльного і європейського права Інституту міжнародних відносин Київського національного університету імені Тараса Шевченка 
Еволюція правових інструментів Євросоюзу забезпечує гнучкість для вироблення найбільш оптимальних та ефективних механізмів забезпечення інтеграційного об'єднання. Форми фіксації норм права Свросоюзу виступають визначальним чинником розвитку європейського інтеграційного об'єднання та мають характерні особливості, акумулюючи в собі елементи джерел міжнародного та внутрішнього права.

Питання джерел права Євросоюзу постійно знаходиться в центрі уваги фахівців в галузі міжнародного і європейського права. При чому дослідження джерел права Свросоюзу наводяться як в аспекті загальнотеоретичного правознавства, так й в аспекті міжнародно-правового аналізу. Зокрема цій темі присвячували свої праці В.Н.Денисов, В.К. Забігайло, С.Л. Зивс, Л. Карту, М. Кремона, Л.А. Луць, Ж.-В. Луї, В.П. Малахов, М.М. Микієвич, В.І. Муравйов, Г.І. Муромцев, Р. Давид, К. Жоффре-Спіноза, Ж.-Л. Сорон тощо. Не дивлячись на прискіпливу увагу доктрини питанням джерел права СС, аспекти еволюції їх розвитку, ієрархії норм, екстериторіальності дії залишаються актуальними для теорії та практики застосування. Варто висвітлити та дослідити основні еволюційні здобутки, що їх привніс Лісабонський договір.

Установчі договори, що формують правову основу для функціонування всієї структури Свросоюзу, творять міжнародний договірний механізм інтеграції, здійснюваної в межах останнього, що являє собою систему міжнародних угод, за допомогою яких спрямовується розвиток інтеграційних процесів у цьому об'єднанні. Такі джерела посідають найвище ієрархічне місце серед інших джерел, через це всі інші акти мають підпорядковуватися цим джерелам і не суперечити їм.

Лісабонський договір надав юридичну силу Хартії Євросоюзу про основні права у редакції 2007 р., яка має таку саму як й установчі договори.

Нововведенням Лісабонського Договору також є включення до основоположних джерел права EC цінностей ЄC (values), які містять моральні засади сучасного етапу розвитку суспільства держав-членів, на яких базується СС. До них відносяться повага до людської особистості, свобода, демократія, рівність, правова держава, дотримання прав людини, дотримання прав осіб, які належать до меншин, плюралізм, недискримінація, терпимість, справедливість, солідарність, рівність чоловіків та жінок (ст. 2 ДСС). При чому недотримання цінностей Союзу державою-членом може мати наслідком застосування до неї санкцій (ст. 7 ДСС). Держави, що бажають вступити до СС, мають поважати цінності Союзу і взяти на себе зобов' язання запроваджувати їх у життя (ст. 49 ДСС).

До системи джерел права Євросоюзу також слід віднести загальні принципи права, спільні для правових систем держав-членів. Правова основа для включення загальних принципів права до правової системи Євросоюзу є опосередкованою і базується на ст. 263 ДФСС. Установчі договори уповноважили Суд СС забезпечувати дотримання законності при їх тлумаченні та застосуванні, що прямо передбачає ст. 19 ДСС. Стаття 6 ДСС визначає, що «основні права, гарантовані Європейською конвенцією про захист прав людини і основних свобод, і передбачені конституційними традиціями, спільними для всіх держав - членів, становлять загальні принципи права Союзу».

Завдяки зникненню специфічних правових інструментів, якими раніше оформлювалися дії в рамках спільної зовнішньої політики і політики безпеки та співробітництва в сфері охорони правопорядку і правосуддя у кримінальних справах, відбулася ліквідація «трьохопорної» структури Євросоюзу. За рахунок спрощення системи правових актів, які раніше приймалися в рамках колишньої «другої» та «третьої» опор, Свросоюз на сьогодні позбувся нагромадження такими актами як спільна стратегія, спільна дія, рамкове рішення і т.д. Ст. 288 ДФСС вказує, що «Для здійснення компетенції Союзу інститути ухвалюють регламенти, директиви, рішення, рекомендації і висновки».

Також, відповідно до ст. 22 ДСС правовим інструментом реалізації спільної зовнішньої політики та політики безпеки стає рішення, що не відноситься до законодавчого типу актів, із спеціальною процедурою його прийняття Європейською радою і Радою Євросоюзу (ст. 31 ДЄС). Крім того, рішенням також можуть врегульовуватись організаційні питання, включаючи уточнення або внесення змін до окремих положень установчих договорів, не змінюючи сферу компетенції Союзу (ст. 48 ДСС). Таким чином через призму різноманітності джерел права СС в цій сфері можна підтвердити наявний дуалізм у сферах правового регулювання.

До одних 3 нововведень Лісабонських договорів слід віднести розмежування законодавчих та незаконодавчих актів в залежності від застосованих до них процедур прийняття рішень. Лісабонський договір запровадив класифікацію правових актів на підставі таких критеріїв як суб'єкт, що видає акт, юридична сила цих актів та процедура їх прийняття. На підставі цих критеріїв правові акти розподіляються на дві категорії: законодавчі та незаконодавчі акти. Законодавчим актом виступає такий правовий акт, який носить юридично обов'язкову силу, що приймається відповідно до законодавчої або спеціальної законодавчої процедури за участю Ради Свросоюзу та Європарламенту (ст. 289 ДФСС). Таким чином, документи, видані Свропейською радою, Комісією 
або Свропейським центральним банком законодавчими актами не визнаються. До незаконодавчих актів відносяться як юридично обов'язкові акти, видані інститутами відповідно до інших процедур їх прийняття, так й рекомендації та висновки, які не носять обов'язкової сили незалежно до інституту, що їх прийняв. Серед незаконодавчих актів виділяються дві підкатегорії актів: делеговані та виконавчі акти. Делеговані акти приймаються Комісією на підставі і в межах повноважень, які делеговані їй в законодавчому акті (ст. 290 ДФСС). Виконавчі акти приймаються Комісією або Радою з метою забезпечення єдиних умов реалізації, які були передбачені в т.зв. «базових» регламентах або директивах.(ст. 291 ДФСС). Відтепер назва відповідного нормативно-правового акту в обов'язковому порядку має віддзеркалювати до якої підкатегорії він відноситься: чи то «делегований» чи то «виконавчий».

Поділ правових актів на категорії законодавчих та не законодавчих не спричиняє запровадження принципу верховенства одних над іншими. Підзаконний характер мають лише делеговані та виконавчі незаконодавчі акти.

На відміну від «типових» актів, ухвалення яких прямо передбачене установчими договорами, існує категорія нормативних актів, які через своє місце в ієрархічній системі не вписується в загальноприйняту номенклатуру. Такі акти в доктрині отримали назву «sui generis» [1; 3; 4]. Ухвалення та систематизація актів sui generis випливають 3 практики права Євросоюзу [2]. До таких актів слід відносити акти, видані поза межами інституційного механізму Євросоюзу, наприклад, акти Євромбудсмана, акти Євроюста чи інших агентств Євросоюзу, які можуть набувати форми заключень, резолюцій, декларацій тощо. Такі акти не входять в систему правових актів відповідно до ст. 288 ДФСС. Також до нетипових актів або актів sui generis слід віднести акти інститутів, що видаються в непередбаченій в установчому договорі формі. Як свідчить практика функціонування інститутів Євросоюзу до такої категорії актів слід віднести повідомлення (communication), білі та зелені книги (white and green papers), керівні настанови (guidelines), кодекси поведінки, резолюції тощо. Із практики діяльності інститутів СС витікає, що повідомлення Комісії покликані раціоналізувати процедуру ухвалення актів у рамках Євросоюзу, зробити їі простішою й відкритішою. Коли набирається велика кількість повідомлень з одного питання, Комісія кодифікує їх у Зелену книгу, а напередодні ухвалення нормативно-правових актів на їхній підставі видає остаточний варіант - Білу книгу.

Юридичний аналіз Білих та Зелених книг породжує неоднозначність у тлумаченні цих актів. 3 одного боку вони мають рекомендаційний характер, тим не менше вони можуть породжувати обов'язкові юридичні наслідки в певних прямо передбачених випадках. Включення до них положень обов' язкових для виконання актів або посилань на них породжує особливу роль цих документів у регулюванні інтеграційних процесів. За необхідності допускається їх оспорювання в Суді ЄС.

У цьому зв'язку слід відмітити, що такі «нетипові» акти СС відносяться до «м'якого» права СС (soft law) [3]. Доктрина м'якого права в Свросоюзі набуває більш активно свого розвитку з середини 90-х років XX століття, що пов'язано із заснуванням самого об'єднання. Європейський правник Ф. Снідер дає більш чітке лаконічне визначення м'якого права в СС. При цьому це визначення $є$ класичним для міжнародного публічного права. У своєму дослідженні він визначає м'яке право, як «правила поведінки, які, в принципі, не мають юридично зобов'язуючої сили, але, попри це, можуть мати практичні наслідки» [2]. Тобто головною ознакою актів м'якого права є те, що всі вони не є офіційно зобов'язуючими, хоча їх можуть дотримуватись й на практиці дотримуються, що зумовлює їх наслідки виконання.

Фундаментальне узагальнене визначення м'якого права в доктрині права СС зробила Л. Сенден. Вона вважає, що «м'яке» право формується з «правил поведінки, які закладені в документах, які не пов'язані юридично обов'язковою силою як такою, але тим не менш, можливо, можуть мати деякі непрямі правові наслідки, які здійснюються і можуть здійснювати практичний вплив» [4].

В західній доктрині права СС існує підхід до поділу його на «тверде» й «м'яке» 3 огляду на юридично обов' язкову силу актів. Так, наприклад, Лука Барані розподіляє «жорсткі» методи правотворчості (наприклад, обов'язкова гармонізація на підставі директив, пряма дія регламентів, обов'язковість рішень Суду (С) та «м'які», під якими розуміється відкритий метод координації, що «використовується в якості платформи для добровільних угод» [5]. Однак, механізми відкритого методу координації є офіційно не визначеними та складаються з практики діяльності інститутів Свросоюзу, тому їх нечіткість зумовлює неможливість їх однозначного віднесення до м’яких методів правотворчості. Взагалі, кажучи про правотворчість, з нашої точки зору, нелогічно виділяти «м'які» методи, 3 огляду на те, що процедури прийняття рішень чітко виписані в установчих договорах.

Своєрідне бачення м’якого права визначив західний правник К. Хілліон. Аналізуючи зовнішні зносини ЄС 3 третіми країнами, він висуває концепцію «добровільного виконання актів рекомендаційного характеру» [6]. Під цими актами він розуміє прийняті рішення, які не носять формально 
юридично обов' язкового характеру, однак на практиці ними керуються в процесі інтеграції третьої країни до ЄС.

3 аналізу доктрини права Свросоюзу можна зробити висновок, що феномен «м'якого права» має своє віддзеркалення як у внутрішній, так і зовнішній політиці об'єднання. Існування нетипових актів вказує на їх особливу правову природу, яка лежить в основі особливої правової природи самого Европейського Союзу.

Окремою групою актів, схвалюваних інститутами Євросоюзу, є насамперед, стимуляційні заходи, або, як їх ще називають, рішення про заохочувальні дії, або заохочувальні дії («incentive measures») відповідно до ст.ст. 149, 165(4), 167(5), 168(4) ДФСС; загальні орієнтири («general orientations») ст. 12.1 и 14.3 Протоколу про Статут Європейської системи центральних банків та Європейського центрального банку; загальні настанови («guidelines») - ст.ст. 121(2), 148(2), 171(1) ДФСС. Об'єднує всі ці нормативно-правові акти процедура їх ухвалення - звичайна законодавча процедура після консультації з Економічним і соціальним комітетом і Комітетом регіонів (ст. 294 ДФСС). До інших нормативно-правових актів можна також віднести орієнтири СЦБ, що видаються 3 метою регулювання кредитно-грошових відносин, у тому числі валютної політики (ст. 12.1. Статуту Свропейської системи центральних банків та ЄЦБ), які за своєю юридичною природою дуже схожі на директиви. Прикладом може слугувати орієнтир ЄЦБ від 10 січня 2001 року «Про встановлення деяких правил з питань переходу у 2002 році до готівкового євро».

Лісабонський договір ввів норму стосовно юридичної сили міжінституційних угод між Європарламентом, Комісією і Радою, які є договірними актами інститутів Євросоюзу. Стаття 295 ДФСС чітко вказує на можливість обов'язкового характеру цих угод.

Для права ЄС властивий постійний розвиток. Систематизація законодавчої практики - це постійна форма впорядкування правової системи. Створення внутрішньо єдиної системи актів є необхідною умовою ефективності правотворчої діяльності. Для законодавчої практики Свросоюзу процеси систематизації є новими за зразком аналогічного процесу в національному законодавстві.

Облік нормативних актів є такою формою систематизації, за якої видані нормативно-правові акти фіксуються в письмовому або автоматизованому порядку. Облік нормативно-правового матеріалу в СС має своє відображення в сучасній розгалуженій мережі електронного віддаленого доступу до системи EUR-lex.

Інкорпорація є такою формою систематизації, за якою нормативні акти визначеного рівня об'єднуються повністю або частково в різного роду збірники у визначеному порядку, наприклад, в хронологічному, алфавітному або системно-предметному. Для СС характерним є послідовність та вибірковість інкорпорації. Інкорпорації підлягають в основному акти щодо співробітництва в сфері простору свободи, безпеки і юстиції. Яскравим прикладом системно-предметної інкорпорації $є$ публікація в 2000 році Шенгенського acquis, що систематизувала норми, що регулюють вільне пересування в межах СС, механізми судового співробітництва та механізми забезпечення безпеки зовнішніх кордонів Євросоюзу. При аналізі законодавства ЄС можна прийти до висновку, що процеси консолідації відбуваються на двох рівнях: на рівні первинного права та на рівні вторинного права Євросоюзу.

На кожному історичному етапі еволюції правопорядку Свросоюзу, що характеризується підписанням договорів, які вносять зміни до установчих документів, відбувається консолідація норм. Підтвердженням цього факту є прийняття та вступ в силу Лісабонського договору, консолідована версія якого увібрала надбання всього кола установчих документів. На рівні вторинного законодавства можна спостерігати тенденцію до зростання процесу консолідації директив та регламентів. Особливістю такого рівня консолідації є неофіційний її характер. Такі процеси властиві зокрема бюджетному, митному, транспортному, антимонопольному праву Євросоюзу.

Ще однією формою систематизації в законодавчій практиці Євросоюзу є кодифікація, за рахунок якої за останні роки найчастіше почали з'являтися регламенти - кодекси. Особливістю цієї форми систематизації є офіційний ії характер. Прикладами можуть слугувати Митний Кодекс у формі Регламенту №952/2013; Візовий Кодекс у формі Регламенту 810/2009; Шенгенський Кодекс про кордони (Регламент 2016/399) тощо.

Варто відзначити, що в праві Свросоюзу намічається тенденція до скорочення кількості нормативно-правових актів, що досягається зокрема через запровадження різних форм систематизації. У зв'язку з цим, варто відзначити, що систематизація законодавства як постійна форма розвитку й впорядкування діючої правової системи притаманна не тільки на рівні національного законодавства, але й властива правовій системі Євросоюзу.

Система джерел права СС також має своє відображення у зовнішній політиці СС по відношенню до третіх країн. У цьому зв'язку слід відзначити, що джерел стають об'єктом для транспонування 
норм права СС у правопорядки третіх країн, якщо відповідне зобов'язання передбачене міжнародною угодою.

Яскравим прикладом цього слугує ратифікована у 2014 році Угода про асоціацію між Україною та ЄС [7]. По всьому тексту Угоди є притаманним відсилки до джерел права СС, як то до первинного (до установчих договорів), так й до вторинного права, а також до судової практики СС. При цьому додатки до Угоди про асоціацію, а саме до Розділу IV та V Угоди, містять переліки нормативно-правових актів СС у різних сферах, які мають бути імплементовані в законодавство України у встановлені терміни. Натомість постає актуальне практичне питання щодо актуалізації таких переліків у зв'язку із динамічністю розвитку права СС.

3 аналізу системи джерел права СС можна констатувати, що acquis ЄС є комплексом «твердого» та «м'якого» права Євросоюзу, включаючи його основні принципи, доктрини та цінності. Отже, наповнення системи джерел права Євросоюзу є набагато вужчим за зміст поняття асquis, яке, крім джерел права Євросоюзу, включає в себе ще й сукупність правових актів необов' язкового характеру, доктрину, рішення Суду СС, рекомендації та домовленості, які виникли за час існування європейських інтеграційних об'єднань і повинні беззастережно сприйматися державами-членами та третіми країнами, що мають договірні відносини з Свросоюзом.

1. Blanquet M. Droit général de l’Union européenne. - Paris: Dalloz, 2006. - P. 229 - 232.

2. European Parliament resolution of 4 September 2007 on institutional and legal implications of the use of 'soft law' instruments (2007/2028(INI)) / / Official Journal. - 2008. - C 187. - p.75-79.

3. Snyder F. Soft Law \& Institutional Practice in the European Community / / European University Institute Working Paper, LAW. - Florence, 1993. - No 93/5. - 18 p.

4. Senden L. Soft Law in European Community Law / Senden L. / / Hart publishing, 2004. - 592 p.

5. Barani L. Hard and Soft Law in European Union: The case of social policy and the Open Method of Coordination // Web-Papers on Constitutionalism \& Governance beyond the State. - 2006. - No.2. $-32 \mathrm{p}$.

6. Hillion C. A new framework for the relation between the Union and its East-European Neighbours / C. Hillion // The European Neighbourhood Policy: A framework for Modernization, EUI Working Papers (Cremona M., Meloni G. eds) .- Law2007/21. - P. 147154.

7. Закон України «Про ратифікацію Угоди про асоціацію між Україною, з однієї сторони, та Європейським Союзом, Європейським співтовариством з атомної енергії і їхніми державами-членами, з іншої сторони» // Відомості Верховної Ради України. - 2014. - № 40. - Ст.2021.

\section{Summary}

Sui generis autonomous law order of the European Union has separate system of legal acts to regulate relations in accordance with the statutory documents of the European integration organizations. Evolution of the EU legal instruments secures stability and effective functioning of the integration union. The EU Law sources are not composed into the constant system that can unify all sources to the comprehensive whole from the one side, and from another side can adjudicate the criteria for its separation into re independent components, unlike sources of national law.

Reforming the European Union in connection with the entry into force of December 1, 2009, the Treaty of Lisbon was necessary for the further functioning of the European Union, its efficiency and its democratization, and the change in the organization of the supranational complex of legal instruments.

Current integration processes show that the 10-year period has been characterized by sustainability and that the EU needs further modernization of its legal system in case of successful Brexit.

Fixing forms of the EU norms are formulated as the determinating factor of the European integration development that have own features accumulating elements of the international and national law sources.

Lisbon Treaty doesn't change the whole system of the sources, otherwise following the practice, the Reform Treaty classifies legal acts into category of legislative and nonlegislative. The division of legal acts into categories of legislative and non-legislative does not lead to the introduction of the principle of supremacy of one over the other. Only delegated and executive non-legislative acts have hierarchy.

By the way of dissolution of legal acts in the framework of the former "second" and "third" pillars the EU obtains single structure and dissolution of its pillars structure. Article 288 TFEU contemplates that the Union shall exercise its competences by the way of adopting regulations, directives, decisions, recommendations and opinions. 
EU law is characterized by continuous development. Systematization of legislative practice is a regular form of regulation of the legal system. Creating an internally unified system of acts is a prerequisite for the effectiveness of law-making activities.

The tendency of systematization of acts was described as well as their role in the EU external relations. It was proved that systematization of legislation as a permanent form of development and streamlining of the current legal system is inherent not only at the level of national legislation, but also inherent in the legal system of the European Union.

From the analysis of the system of sources of EU law, it can be stated that the EU acquis is a complex of "hard" and "soft" EU law, including its basic principles, doctrines and values. Thus, the content of the system of sources of EU law is much narrower than the meaning of the concept of acquis, which, in addition to the sources of EU law, also includes a set of legal acts of a non-binding nature, doctrine, decisions of the Court of Justice, recommendations and arrangements that have arisen during existence. European integration associations and should be unconditionally accepted by Member States and third countries that have contractual relations with the European Union. 